\title{
Issue 62
}

I. GEOGRAPHY OF RECREATION AND TOURISM: THEORETICAL AND APPLIED ISSUES

Braslavska O.V. SYSTEMIC ANALYSIS OF FACTORS OF THE ATTRACTIVENESS OF THE TERRITORY AS A COMPONENT OF THE TOURIST AND RECREATION POTENTIAL

Mashika H.V., Nych T.V. GEOPOSPATIAL ORGANIZATION OF TOURIST AREAS IN THE CONTEXT OF RECREATIONAL NATURE MANAGEMENT

Kizyun A.H. TRANSNISTRIA OF PODILLIA AS A MODEL REGION FOR THE EXTREME TOURISM DEVELOPMENT

Opria B.O., Opria I.A. TOURIST RESOURCES AND PROBLEMS OF THEIR USE (EXAMPLE KAMIANETS-PODILSKYI, UKRAINE)

II. CURRENT PROBLEMS OF SOCIAL GEOGRAPHY AND COUNTRY STUDIES

Melnychuk A.L., Moskalenko A.M. VOLUNTARY ASSOCIATION OF TERRITORIAL COMMUNITIES AND ADMINISTRATIVE COMPLETION OF UKRAINIAN

ADMINISTRATIVE-TERRITORIAL SYSTEM REFORM: SOLUTIONS AND FORMATION OF DEVELOPMENT PROBLEMS

Puhach S.O. TERRITORIAL FEATURES OF FACEBOOK AND INSTAGRAM SOCIAL NETWORKING SERVICES DISTRIBUTION IN IVANO-FRANKIVSK REGION

Zapototska V.A., Hnatiuk V.V., Hnatiuk S.S. RESIDENTIAL LANDSCAPES OF THE CITY ZDOLBUNIV: HISTORY OF FORMATION AND PROSPECTS OF TRANSFORMATIONS 


\section{Issue 62}

Written by Administrator

Monday, 24 January 2022 15:26 - Last Updated Friday, 28 January 2022 16:40

III. NATURAL GEOGRAPHY: THEORY AND PRACTICE

Kalko A.D., Melniychuk M.M., Uevich S.D., Kalenikov B.I. ANALYSIS OF TRANSFORMATION OF WATER AND LAND RESOURCES UNDER THE INFLUENCE OF DRAINAGE RECLAMATION IN VOLYN REGION

INFORMATION ABOUT AUTHORS

1. Braslavska Oksana Vladimirovna - Doctor of Pedagogical Sciences, Professor, Pavlo Tychyna Uman State Pedagogical University, Head of the Department of Geography and Methods of Teaching, Uman, Ukraine, e-mail: oksana.braslavska@udpu.edu.ua.

2. Hnatiuk Viktoriia Volodymyrivna - Geography Teacher of the Highest Category, Teacher Methodologist of Zdolbuniv Secondary General Education School for Levels I-III № 6, Zdolbuniv, Rivne Oblast, Ukraine, e-mail: victoriahnatiuk@ukr.net.

3. Hnatiuk Svitlana Serhiivna - Student of Economic and Social Geography Department, Faculty of Geography, Taras Shevchenko National University of Kyiv, Kyiv, Ukraine, e-mail: svetahnatiuk@ukr.net.

4. Zapototska Viktoriia Anatoliivna - PhD Geography, Assistant of Economic and Social Geography Department, Faculty of Geography, Taras Shevchenko National University of Kyiv, Kyiv, Ukraine, e-mail: vzapototska@ukr.net.

5. Kalenikov Bogdan Ivanovich - Undergraduate, Polissya National University, Zhytomyr, Ukraine.

6. Kalko Andrii Dmitrovich - Doctor Of Geographical Sciences, Professor, Internetional University Of Economics And Humanities Academician Stepan Demianchuk, Rivne Ukraine, e-mail: edissey@meta.ua. 


\section{Issue 62}

7. Mashika Hanna Vasylivna - Doctor of Geographical Sciences, Associate Professor, Head of Tourism Department, Uzhhorod National University, Uzhhorod, Ukraine, e-mail: mashika.g.v.@i.ua.

8. Melnychuk Anatoliy - Candidate of Geographical Sciences, Associate Professor, Assistant Professor of Economic and Social Geography Department, Faculty of Geography, Taras Shevchenko National University of Kyiv, Kyiv, Ukraine, e-mail: melan97@ukr.net.

9. Melniychuk Michaylo Michaylovich - Candidate Of Geographical Sciences, Associate Professor, Assistant Professor of Physical Geography Department, Volyn National University named by Lesia Ukrainka, Lutsk, Ukraine.

10. Moskalenko Anna-Maria - Student of Economic and Social Geography Department, Faculty of Geography, Taras Shevchenko National University of Kyiv, Kyiv, Ukraine, e-mail: alla_moskalenko@ukr.net.

11. Nych Tatiana Vasilievna - Ph.D. in Geography, Assistant Professor of Economic and Social Geography Department, Faculty of Geography, Taras Shevchenko Kyiv National University, Kyiv, Ukraine, e-mail: tatyana2510@ukr.net.

12. Kizyun Alla Hryhorivna - Candidate of Geographical Sciences, Associate Professor, Assistant Professor of Geography, Department, Faculty of Natural Geography, Vinnytsia Trade and Economic Institute KNTEU, Vinnytsia, Ukraine, e-mail: vdpugeo2014@gmail.com.

13. Opria Bohdana Oleksiivna - Candidate of Historical Sciences, Associate Professor, Kamianets-Podilskyi National Ivan Ohiienko University, Kamianets-Podilskyi, Ukraine, e-mail: bogdana.oprya@gmail.com, https://orcid.org/0000-0001-6751-1030.

14. Opria Ihor Anatoliiovych - Candidate of Historical Sciences, Associate Professor, Kamianets-Podilskyi National Ivan Ohiienko University, Kamianets-Podilskyi, Ukraine, e-mail: 
igoroprya555@gmail.com, https://orcid.org/0000-0003-2847-2088.

15. Puhach Serhii Oleksandrovych - Candidate of Geography, Associate Professor, Assistant Professor of Economic and Social Geography Department, Faculty of Geography, Lesia Ukrainka Volyn National University, Lutsk, Ukraine, e-mail: puhachserhiy@gmail.com, https://orcid.org/0000-0002-3738-7961, Scopus ID: 57210165064.

16. Uevich Sergii Dmitrovich - Candidate Of Geographical Sciences, Associate Professor, Volyn National University named by Lesia Ukrainka, Lutsk, Ukraine. 